\title{
A GIRL WHO PAINTS
}

\section{Moran Sheleg}

'Good little girls ought not to make mouths at their teachers for every trifling offence. This retaliation should only be resorted to in peculiarly aggravated circumstances.' Mark Twain, Advice to Little Girls (1867)

s part of her article for a special issue of Artforum, published in
20 I i, the Brooklyn-based artist Amy Sillman included a digitally
reworked scene lifted from Ernie Bushmiller's classic I93os comic strip following the exploits of a precocious little girl named Nancy (figure I). ${ }^{2}$ Re-imagining an encounter between the comic's title character and another, on whom she spies through a hole in the fence that divides them, in Sillman's version baseball is substituted for a second quintessentially American - and supposedly male - activity: action painting. One can clearly see where the image has been adapted, the character's mitt replaced with a palette and paintbrush. 'Wow,' Nancy remarks as he runs, now with palette in hand, 'what a painting!' (rather than 'what a pitch'), before offering, to her acquaintance's visible surprise, a token of admiration: a bite of candy. Within her accompanying text, subtitled 'In Defense of Abstract Expressionism II', Sillman references T.J. Clark's I994 essay of the same title, building on the art historian's recognition of the 'vulgarity' of this much maligned and 'embarrassing' artistic legacy, situated in a similarly stereotypical, machismoladen, and inaccessible domain as that glimpsed by her girl. ${ }^{3}$

Serving as an illustration in a double sense, it is along parallel lines to Nancy's outsider (almost voyeuristic) position that in her article Sillman recalls the prospect painting presented during her days as 'a little under-grad painter-girl (...) an earnest student with an old-guard teacher,' a teacher described as: 

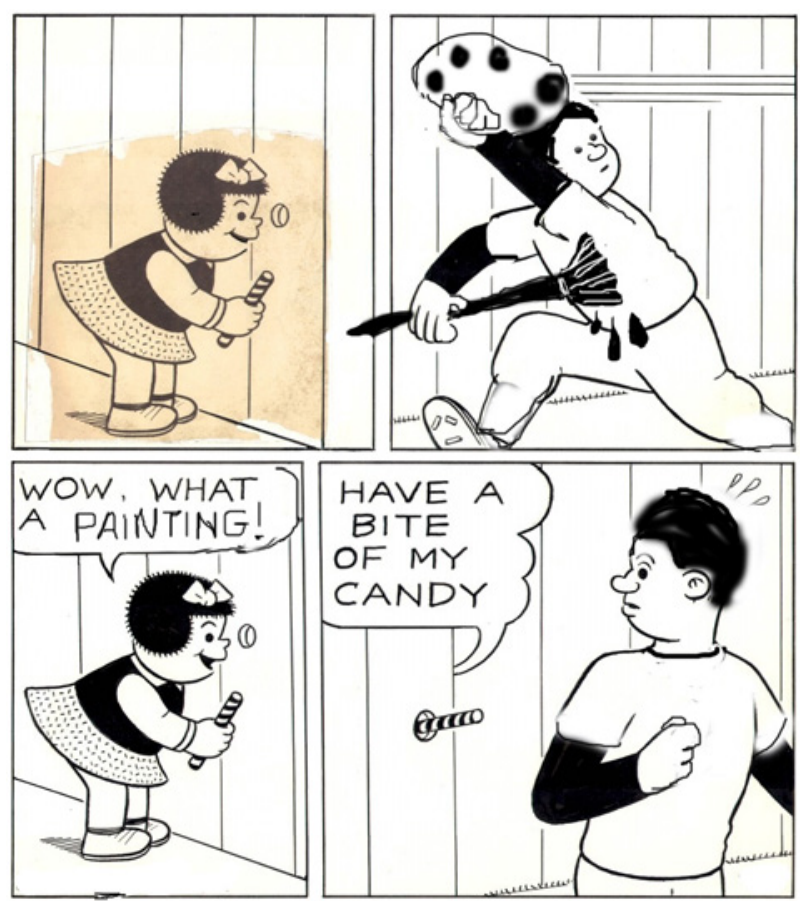

Figure I Amy Sillman, Nancy (thank you to Bushmiller and Brainard), 20 I I. Digitally altered comic strip. (C) Amy Sillman. Courtesy of Sikkema Jenkins \& Co., New York.

one of those former AbEx party members who had gotten himself a teaching gig. I didn't like him, and he warned me in return that I would certainly fail as an artist, but he was the only painter I knew, and he played Sinatra in class and called Abex "action painting," which sounded exciting, and I wanted to have his clichés and eat them, too. ${ }^{4}$

With its informal yet direct tone, Sillman's text and drawing (or re-drawing) marshal the spirit of Mark Twain's short piece Advice to Little Girls (I 867), an irreverent guide to public relations for the young, detailing how to deal with irksome people such as parents, playmates, little brothers, old people, and most pertinently - teachers. ${ }^{5}$

Whilst clearly savouring such archaism, at the heart of Sillman's comical exchange lie some serious questions about the "peculiarly aggravated 
circumstances' demarcating gestural painting and its legacies. 'How is it,' she asks in the accompanying essay, 'that, despite the complexity of AbEx, its reputation has boiled down to the worst kind of gender essentialism?' The kind which, failing to get beyond 'simple butch and femme role-playing,' has obscured the 'interesting vagaries and conflicts' animating its 'gender clichés,' such as 'the fact that (Lee) Krasner was man enough to bend hot-pink planes with her bare hands, and the fact that (Joan) Mitchell was no feminist." Pointing to the pervasiveness of the catchall term 'woman artist' as a label synonymous with 'identity-oriented politics,' Sillman highlights the limiting quandary of the often-recognized yet little qualified 'misogyny of the New York School,' as Krasner herself described it, which ironically enough would appear not to have excluded women. ${ }^{7}$

Given this longstanding problem it seems pertinent that Sillman alights on the image of a perpetual girl, in the form of Nancy, to picture her scene. Following developments in the study of 'girl culture' in sociology, anthropology, and cultural theory since the I990s, the representation of the 'girl' and 'girlhood' in contemporary art has emerged as an area of critical enquiry and a specific strand of feminist art history. As posited in a recent volume of essays edited by Lori Waxman and Catherine Grant, the appearance of this aesthetic phenomenon has raised 'questions about the state of feminism, sexuality and identity' as asked 'by a diverse range of contemporary artists for whom politics are ambiguously blended alongside the associations of girlhood with spectacular consumer culture. ${ }^{8}$ Seeming to anticipate these sentiments, in a text written for the 20 I Feminism! issue of Texte zur Kunst, Sillman asserts that:

Identity politics hasn't kept us all bracketed away from each other in separate self-serving units, but has allowed for the luxury of folding gender questions together with all the other things that interest us, like form, colour, history, memory, affect, meaning, visuality, etc. ${ }^{9}$

One such entanglement emerges in the clump of marks that cover Sillman's large canvas Big Girl (2006), a towering structure in which the 'self' of selfportraiture and self-reflexive painting seem inextricably bound (figure 2). Whilst Helen Molesworth sees Sillman's work as the materialization of 'what it feels like when you feel like a girl - that is, when you feel like a person 


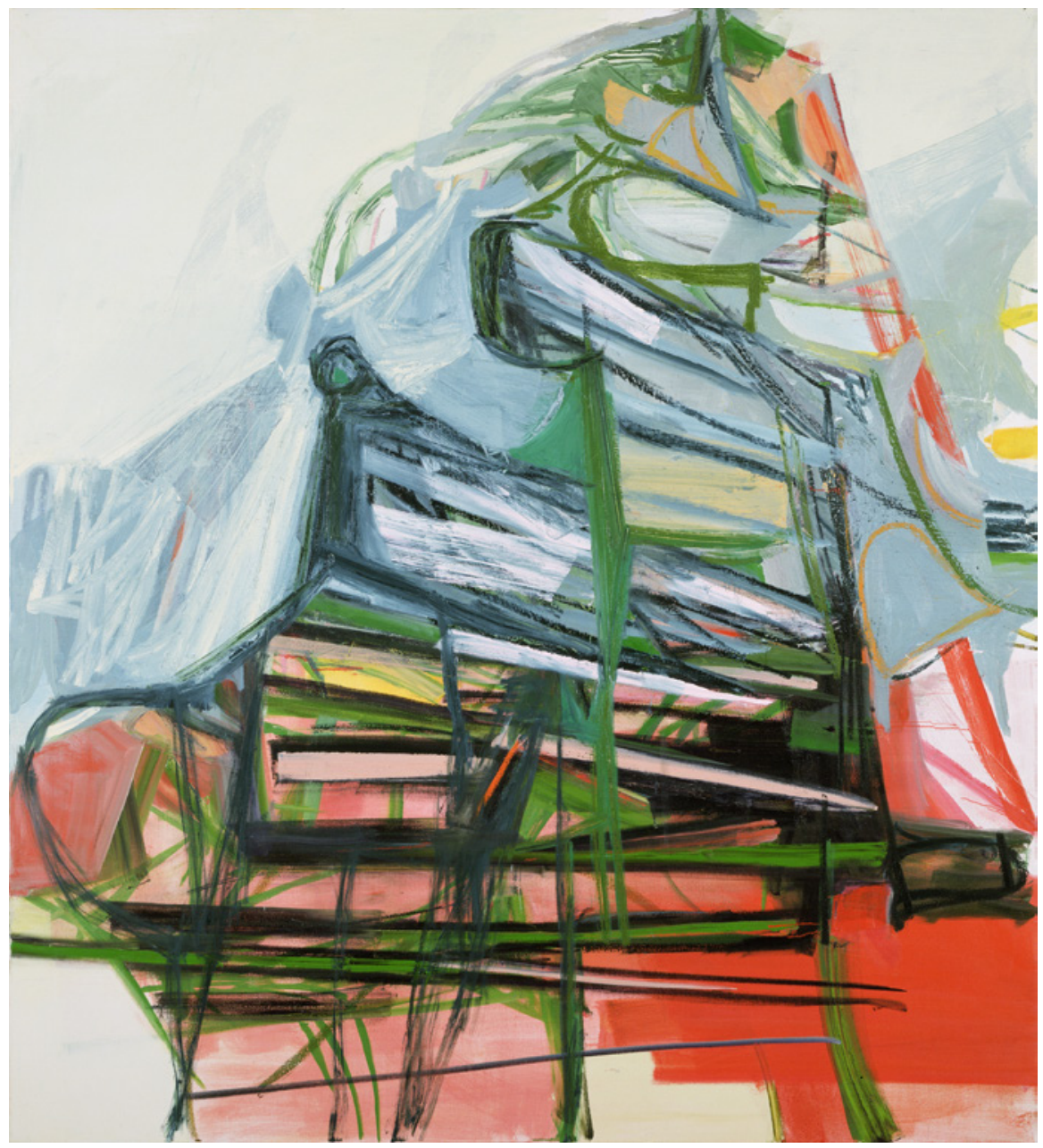

Figure 2 Amy Sillman, Big Girl, 2006. Oil on canvas, $203.2 \times$ I $82.9 \mathrm{~cm}$. Amy and Vernon Faulconer Collection, Dallas, Texas. (C) Amy Sillman. Courtesy of Sikkema Jenkins \& Co., New York. Photo: John Berens.

who is being watched and judged for her ability to withstand being watched and judged,' it also stands as the self-made proposition of a girl who watches and judges in return. ${ }^{\mathrm{IO}}$ In a second version of the cartoon (figure 3 ), the action of the pitcher-turned-painter is supplemented by a now visible, if still incomplete, painting. Yet, as before, it is the interaction with the painter 

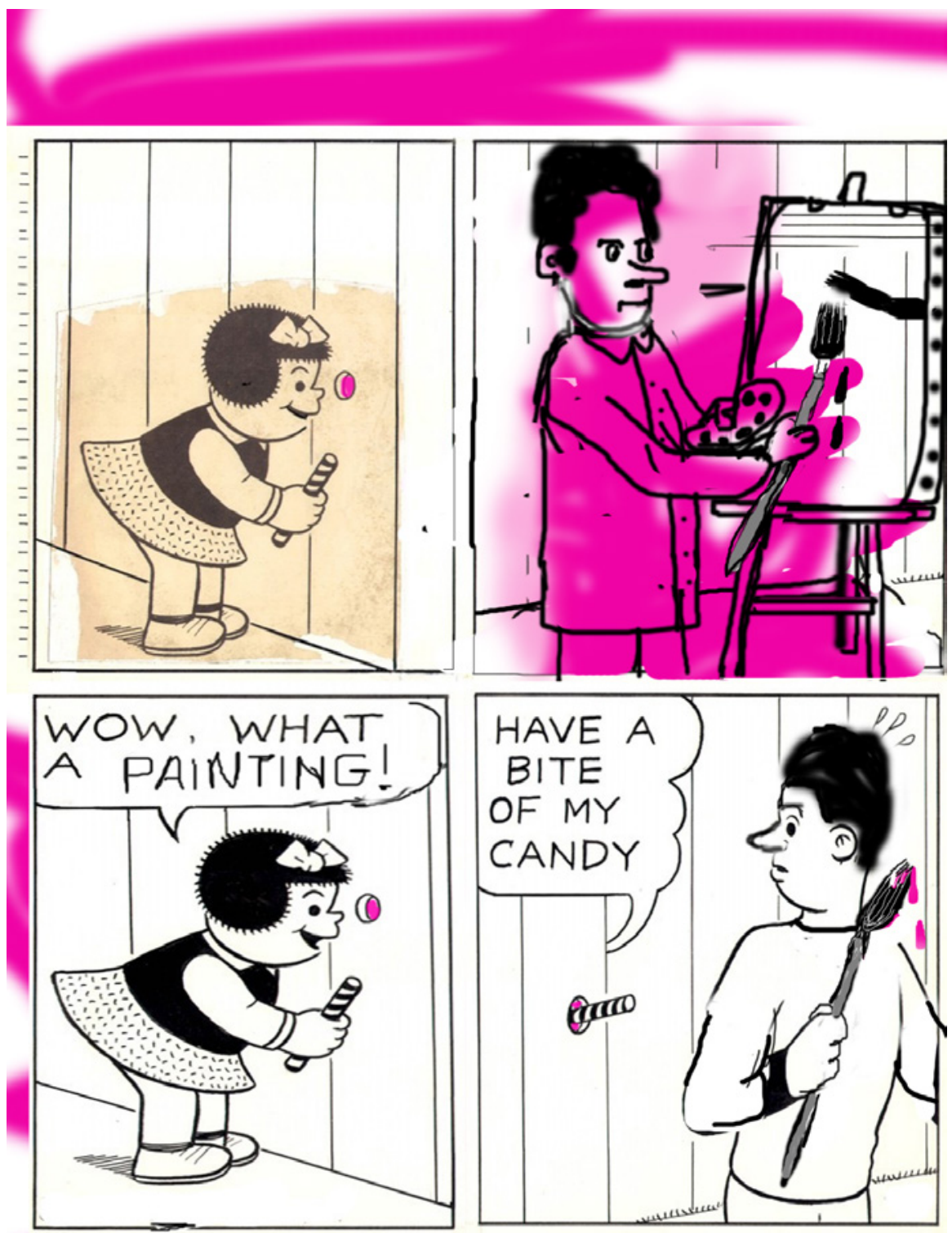

Figure 3 Amy Sillman, Nancy 2 (thank you to Bushmiller and Brainard), 20 I I. Digitally altered comic strip. (C) Amy Sillman. Courtesy of Sikkema Jenkins \& Co., New York. 
as instigated by Nancy to which our attention is drawn. In Sillman's hands, painting is both represented and re-presented as the catalyst for a point of contact, if only through a small gap in a seemingly insurmountable, but not impenetrable, barrier.

As part of an attempt to stage such an opening into painting's past, in 2008 Sillman was invited to select works by her chosen precursors for a group exhibition titled Oranges and Sardines: Conversations on Abstract Painting, curated by Gary Garrels and held at the Hammer Museum in Los Angeles. ${ }^{\text {I }}$ In the accompanying catalogue, Sillman explains the significance of $H+H$ (I965), a painted relief by Eva Hesse (figure 4), to her own work. As she states:

These works represent what abstraction is to me, homing in on the ideas of colours, shapes, anxieties, eccentricities - a kind of vector where the psychological works itself out through the formal. My thinking about everything for this exhibition starts with the Hesse. ${ }^{\mathrm{I} 2}$

Here Sillman positions as her point of entry a work made at a moment often critically framed as Hesse's departure from painting. Completed and first exhibited by Hesse during an extended stay in Germany (the country she had to flee as a three-year old child, on account of being a Jew), $H+H$ is one of a group of fourteen masonite and wood panels mounted with rope, machine-parts, and masking tape, amongst other materials, all saturated with a vivid spectrum of coloured ink and paint. These surviving reliefs, many of which remained in Europe, constitute what has repeatedly been referred to as Hesse's decisive 'breakthrough,' soon solidifying into the sculptural work begun following her return to New York in the autumn of $1965 .{ }^{\mathrm{I}}$

What might it mean for Sillman, an artist concerned with the ambiguouslygendered, historical grey zones of abstract gestural painting, to choose such an 'exit' as her own entrance? ${ }^{\text {I4 }}$ What kind of 'historicity,' to quote Yve-Alain Bois following Hubert Damisch, might Sillman's choice suggest, and what implications might it hold for a critical reappraisal of the status of painting during the mid-I960s, a moment often viewed as the horizon of its supposed 'end'?'s

In the face of these questions, Hesse's own paintings offer a prominent and appropriately problematic case study with which to test both the 


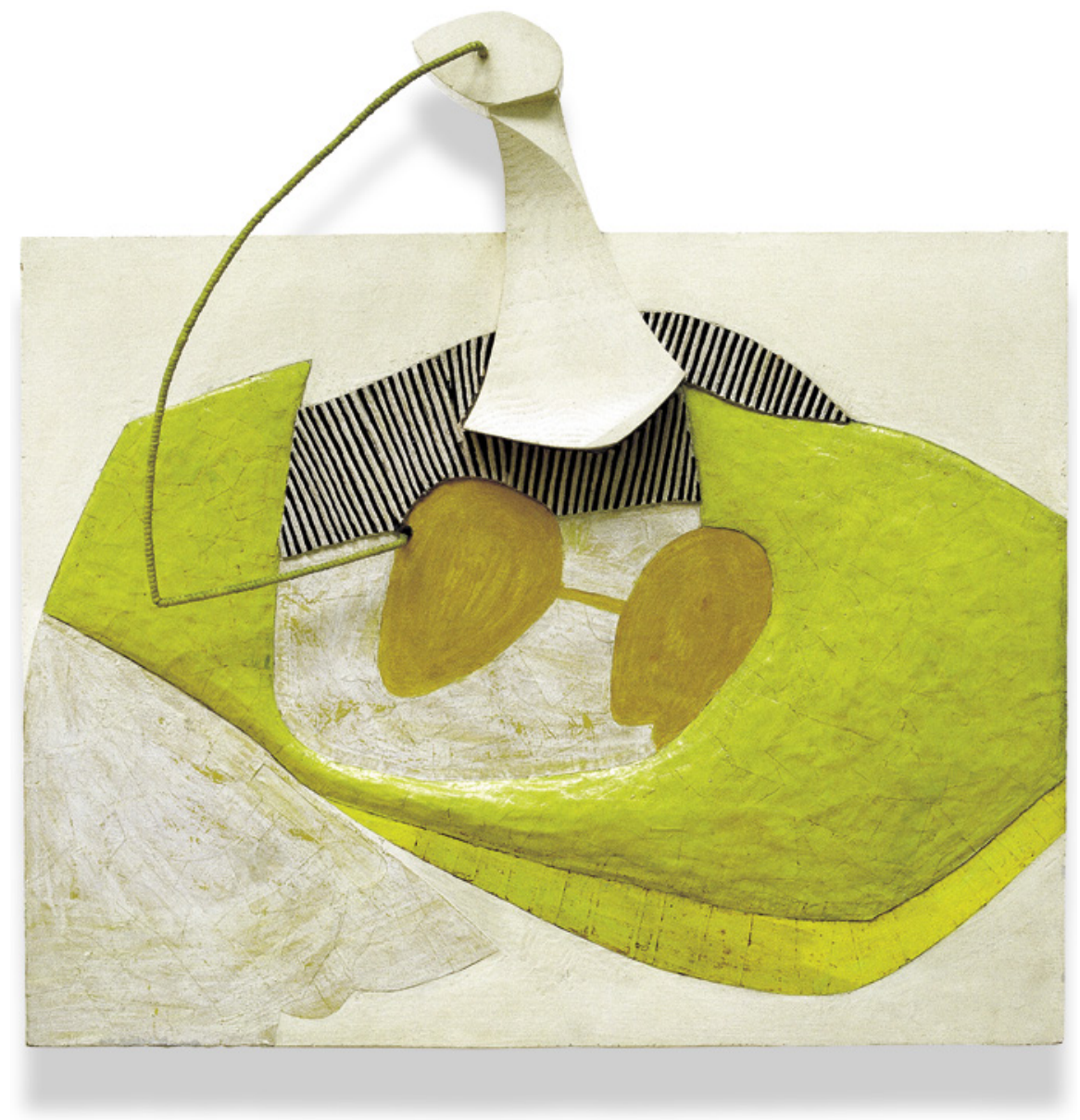

Figure 4 Eva Hesse, $H+H$, June I965. Varnish, ink, gouache, enamel, cord, metal, found object (wood), papier-caché, unknown modeling compound, particle board, wood, $68.6 \times 69.9 \times$ I $2.4 \mathrm{~cm}$. Ursula Hauser Collection, Switzerland. (C) The Estate of Eva Hesse. Courtesy Hauser \& Wirth.

condemnation and reclamation of painting - often, in the first instance, by the artist herself - during a moment today wagered as proto-feminist. Yet a moment which, despite its urgent remapping since the I970s, still remains something of an art historical no-woman's-land, as evidenced by even the most recent scholarly reappraisals in which women feature solely as the objects and pictorial products of 'post-war' painting, as opposed to its producers. ${ }^{\mathrm{I}}$ 


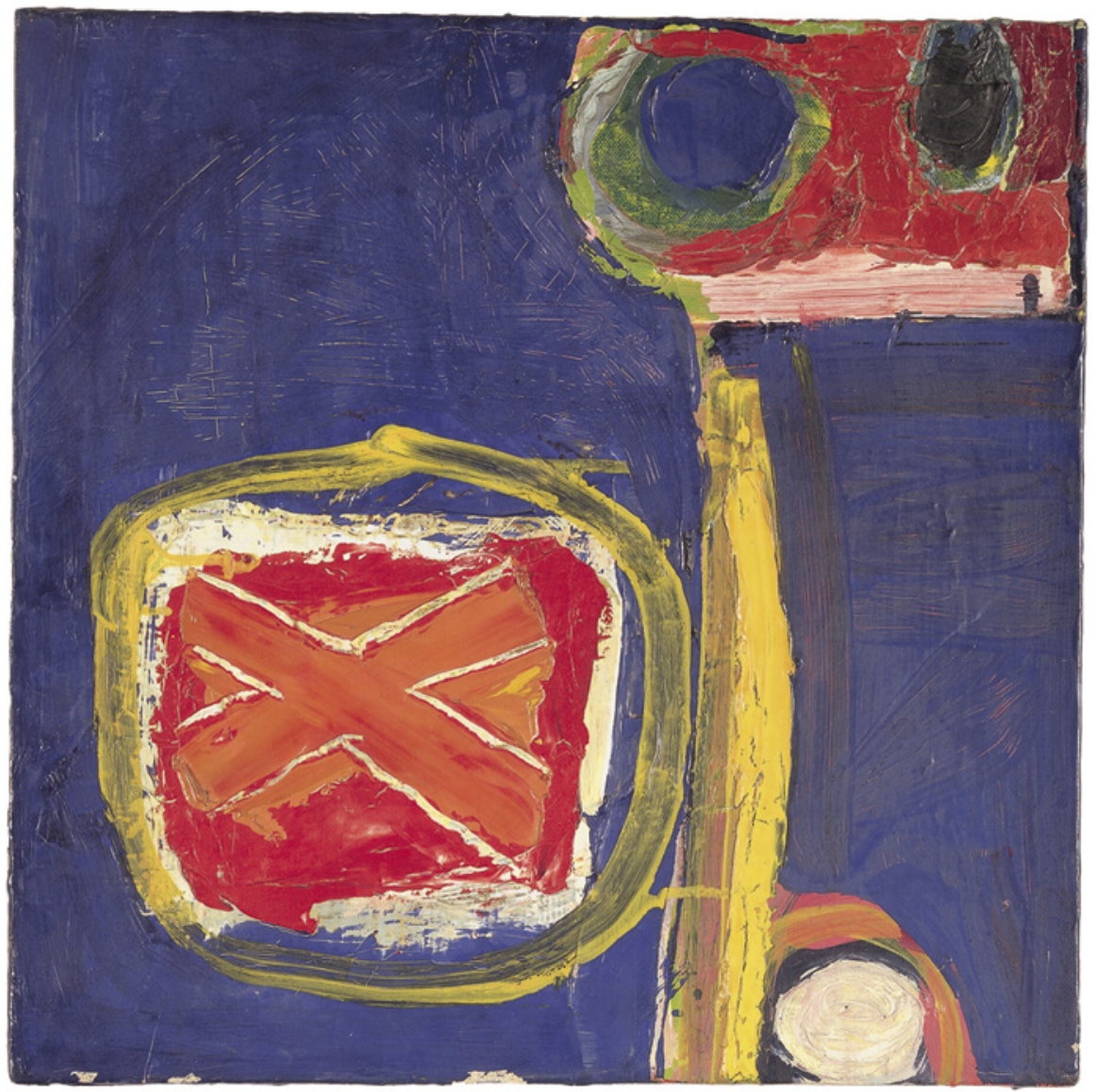

Figure 5 Eva Hesse, No title, I96I. Magna on canvas, $40.7 \times 40.7 \mathrm{~cm}$. Collection of Raina Lynn, Westwood, New Jersey. (C) The Estate of Eva Hesse. Courtesy Hauser \& Wirth. Photo: Abby Robinson, New York.

The hangover of the discursive figure of the 'woman painter' here appears to linger, positing a problem area for art historical accounts hitherto unable, or else unwilling, to account for her. ${ }^{17}$

In the case of Hesse's paintings, this critical dismissal has proved endemic from the outset. ${ }^{18}$ Although manifesting formal kernels, such as the primarycoloured palette and 'predilection for "painting out" around shapes,' (see, for example, figure 5), the vast majority of the artist's production as a painter receives no mention in Lucy Lippard's key monographic study, which still 
stands as a foundational resource. ${ }^{19}$ Important though Lippard's book was, the palpable need to canonize Hesse's 'mature' work - that is, the sculptural practice that would emerge over the last four years of the artist's life - has had the polarizing effect of reinforcing the de facto neglect of her disparagingly categorised 'embryonic' and 'early' output, constituting the hundred or so predominantly abstract canvases of various sizes and visual schemes that the artist produced after graduating from Yale Art School in I959. ${ }^{20}$ In tangential agreement, Hesse's friend and colleague Mel Bochner has asserted that prior to her return to America, 'she wasn't doing work that was consistently good enough to show.' ${ }^{21}$ This indictment, however, seems to speak more to Bochner's own 'bracketing out' of what he has described, in reference to his ostensible return to painting in the I980s, as the 'pejorative' labels of the 'compositional' and the 'subjective' then attached to the contentious medium, than it does to the status and reception of Hesse's so-called 'early' work. $^{22}$

When compared, a palpable distinction can be seen between the artists' projects at the time. Whereas Bochner's excessive layering of colour on masonite board (figure 6) results in a lumpy patch of brown pigment, a sort of Robert Rauschenberg-esque scatological experiment emphasizing the base 'materiality' of oil paint, Hesse's canvas (figure 5), painted with the solvent-based acrylic Magna, appears more concerned with building up an abstract visual vocabulary in which enclosed shapes partition the picture plane, a governing strategy in much of her subsequent art. ${ }^{23}$ Whilst Hesse's work does not totally obscure the traditional formula of painting as tableau, neither does it fully relinquish hold of the canvas as a space of agency - a remnant of the artist's 'action,' as famously posed by Harold Rosenberg in $1952 .{ }^{24}$ In order to broach what may have been at stake in upholding the kind of 'phenomenology of making' available in abstract gestural painting ten years post factum, not only of the main event but also its almost immediate lampooning and quite literal 'erasure,' to recall Rauschenberg again, I want to argue that Hesse's works reverse the logic of the 'pejorative' terms identified by Bochner. ${ }^{25}$ For rather than putting them aside, Hesse's canvases elicit, exaggerate, and even relish the muchmaligned and 'vulgarised' aspects of abstract expressionist painting - to return to Clark's defense - precisely by displacing its founding phallocentric tenets. ${ }^{26}$ 


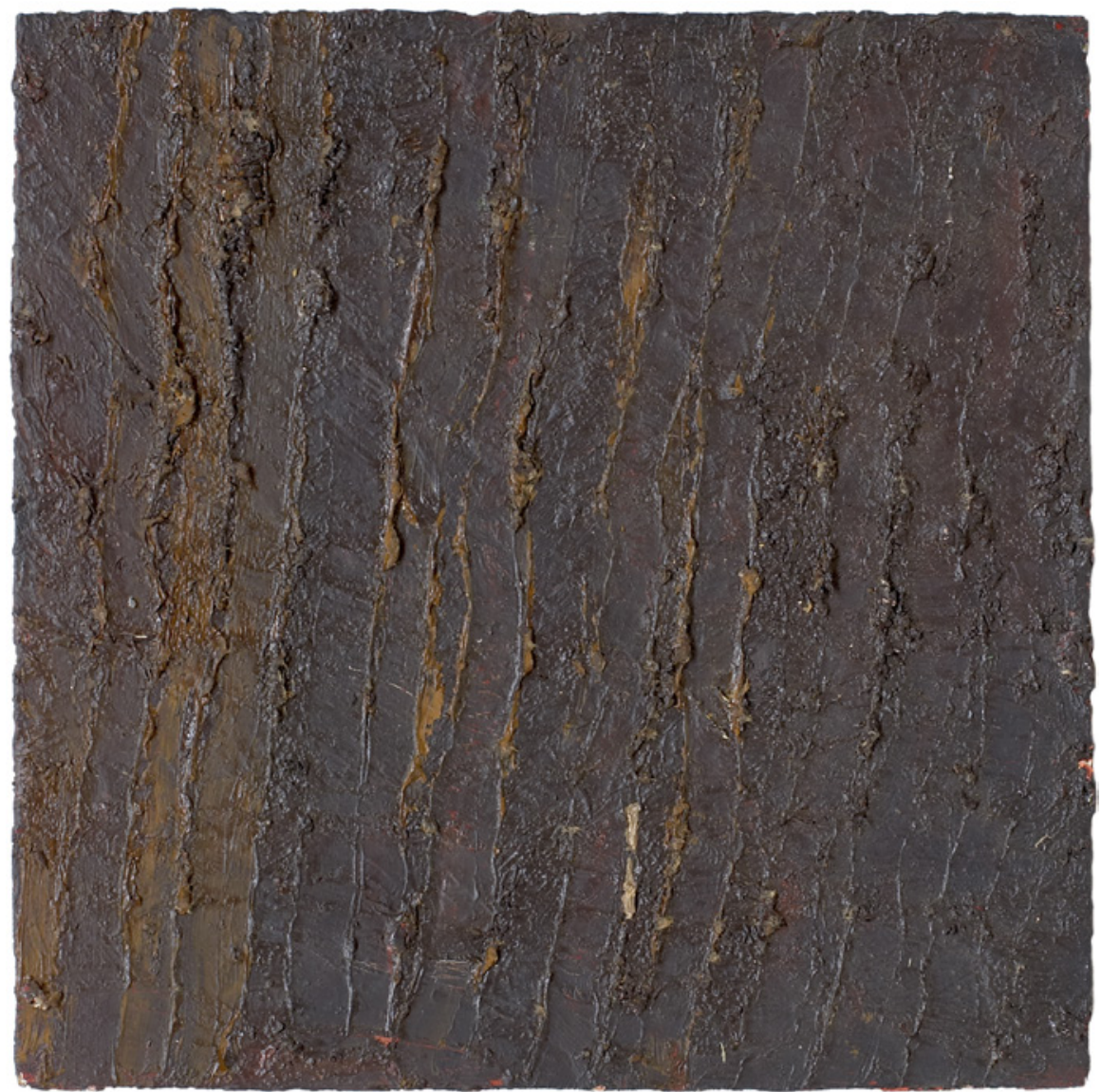

Figure 6 Mel Bochner, Untitled, I964. Oil on masonite, $30.5 \times 30.5 \mathrm{~cm}$. Collection of the artist. (C) Mel Bochner.

Writing in I992 for the earliest exhibition to focus solely on Hesse's large abstract paintings, which included Untitled of I964 (figure 7), Max Kozloff identifies the 'cockiness - and contrariety' of its 'cartoonish' elements as a rejection of 'the feminine side' of Arshile Gorky's work, namely his 'insinuating hothouse colours' and 'aromatic exaltations. ${ }^{27}$ Not quite able to move beyond the 'gender essentialism' highlighted by Sillman however, Kozloff describes Hesse's parodic twist of an admired forbear's bodily, and distinctly erotic, imagery as 'a necessary payment of dues in the male art world. ${ }^{28}$ On the other hand, Kirsten Swenson suggests Untitled as a more or 


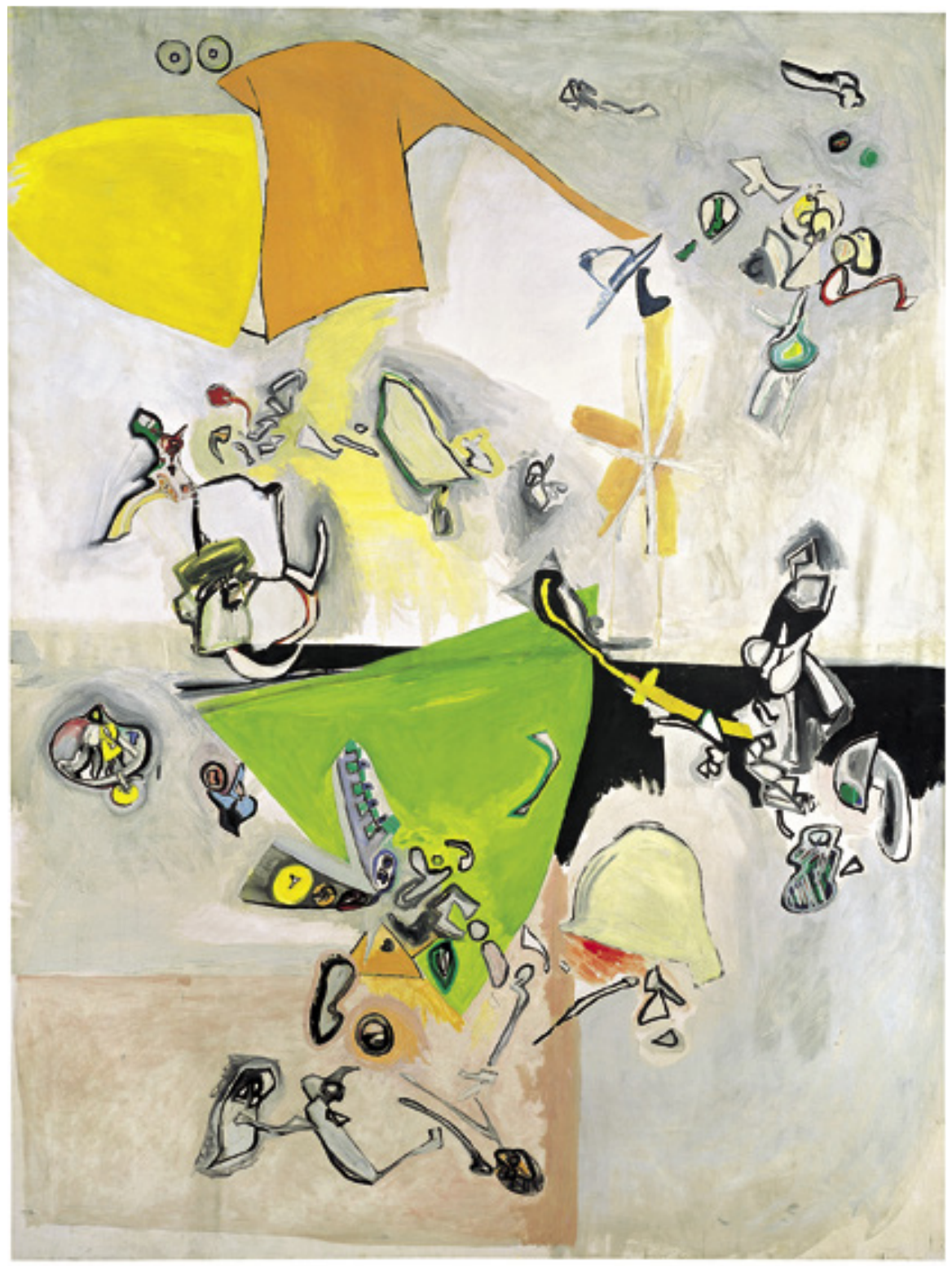

Figure 7 Eva Hesse, Untitled, I964. Ölfarbun, Bleistift und Collage (Leinwand) auf Leinwund, H: 200, B: I $50 \mathrm{~cm}$. Kunstmuseum Winterthur, Presented by the Volkart Foundation, 2009. (C) Hans Humm, Zürich. 
less direct remodelling of one of Gorky's Betrothal paintings belonging to the Yale University Art Gallery, which she claims the artist had been familiar with since her student days. Swenson goes on to interpret the work as 'an expression' of Hesse's frustration with traditional marriage designations, and the incompatibility of the roles of 'artist' and 'wife' as she experienced them at the time. ${ }^{29}$ Whilst I do not wish to understate these challenges, viewing Hesse's paintings solely through the biographical lens that Swenson proposes (or else Anna Chave's anthropomorphic take on the later objects in terms of 'a girl being a sculpture') risks eliding what Bochner has called 'the problem' of 'the Eva Hesse "mythology"' surrounding the artist's work, at the expense of its critical appraisal. ${ }^{30}$ Consequently, the shifting concept of the girl offers a useful pivot around which to unhinge the framing of these paintings as biographical self-portraits, stylistic ventriloquisms of - in Kozloff's words - 'idolised patriarchs', or failed attempts to sustain a 'dialogue' with art history. ${ }^{3 \mathrm{I}}$

In her study on feminine adolescence in popular culture and cultural theory, Catherine Driscoll identifies the girl as a 'historically specific' construction of cultural discourse, 'an index' of broad cultural changes and continuities in modernity, cited as a time privileging the person as 'the knowing centre of the world.' ${ }^{32}$ Distinguishing girlhood as a set of historical fictions surrounding the experience of becoming a woman, Driscoll traces the emergence of the girl as a mutable discursive locus shaped, in part, with the involvement of young women themselves. Accordingly, as both the visible 'marker' of a particular subjective experience, and the maker of a culture specific to it, the concept of the girl as a destabilising rubric helps to consider the possibility of Hesse's paintings as parallel attempts at self-generation by someone who precisely in having occupied this subject position is excluded from standing accounts of the experimental strategies at work in, and the subjectivity mined by, mid-twentieth-century painting. ${ }^{33}$

Reclaimed by later generations of artist and activist collectives such as the Guerrilla Girls and Riot Grrl groups, the upholding of the girl as a critical (and empowering) cultural term, rather than one of condescension, offers a further way of rethinking the gestural aspects of Hesse's paintings beyond the supposed fixity of the 'female identity' of the artist and the gendered body in painting, as well as the body of painting itself - that is to say, of painting as a body. ${ }^{34}$ For whilst the sumptuously coloured, ovoid 


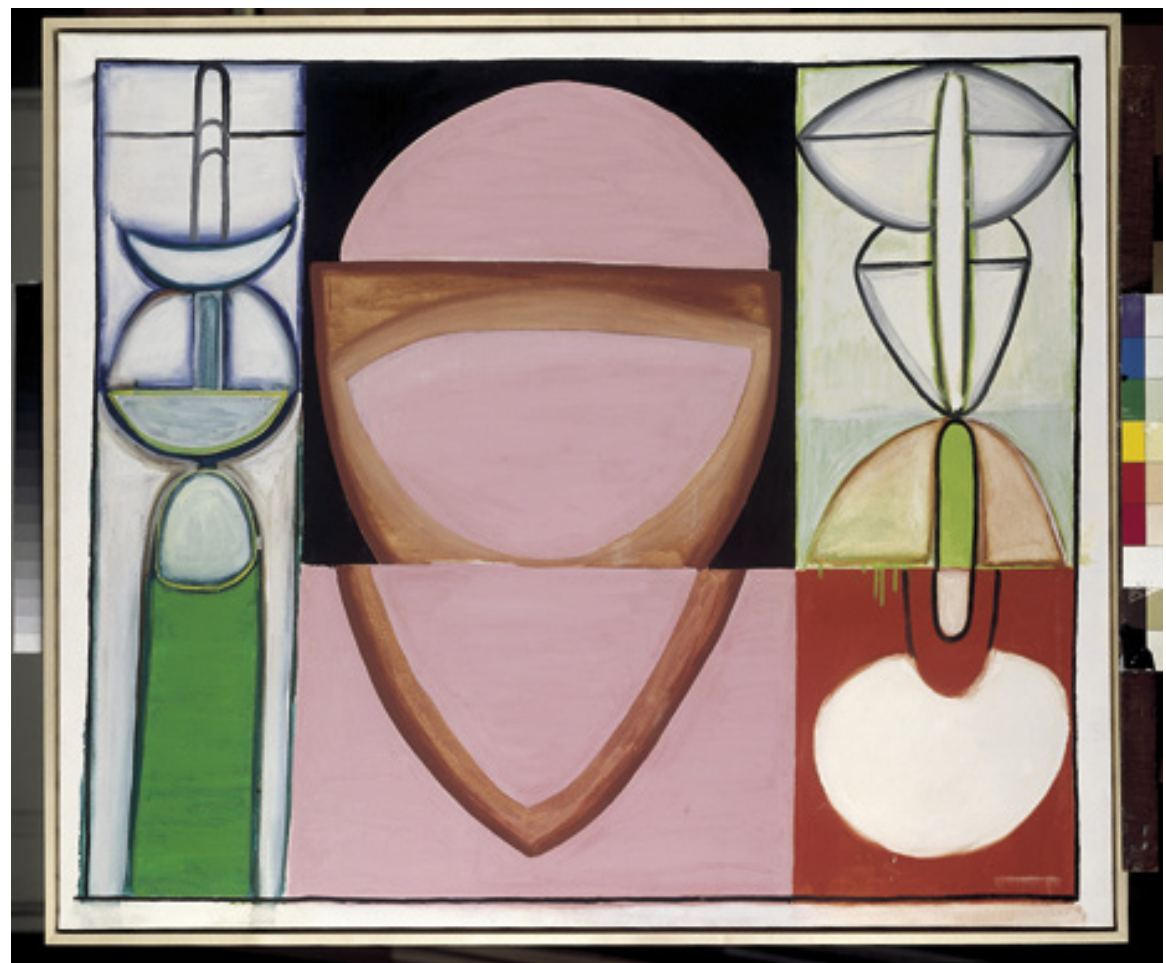

Figure 8 Eva Hesse, Untitled, I965. Ölfarbun auf Leinwand, H: 87.5, B: I04.5cm. Kunstmuseum Winterthur, Purchased with funds from the Lottery Fund of the Canton of Zürich, I993. (C) Hans Humm, Zürich.

forms variously segmented and framed in one of her last canvases (figure 8) might suggest the kind of elemental, even primordial, essence as evoked in the egg-shaped Spatial Concepts of Lucio Fontana, their resolute flatness belies the material emphasis of the canvas as a bodily substitute vulnerable to abjection and mutilation. ${ }^{35}$ Where Fontana's piercing of the surface disrupts the physical cohesion and sublime ideological form of his canvaseggs, suggestively subtitled La Fine di Dio (The End of God), Hesse's cut remnants operate on a deflationary rather than a destructive principle, by which sexual allusion appears perfunctory rather than provocative. ${ }^{36}$ Take for example the collaged scraps of painted paper that form Penetration of 1965 (figure 9), which, whilst knowingly euphemistic, just as graphically diagram the piecing together of a particular visual vocabulary commandeered from 


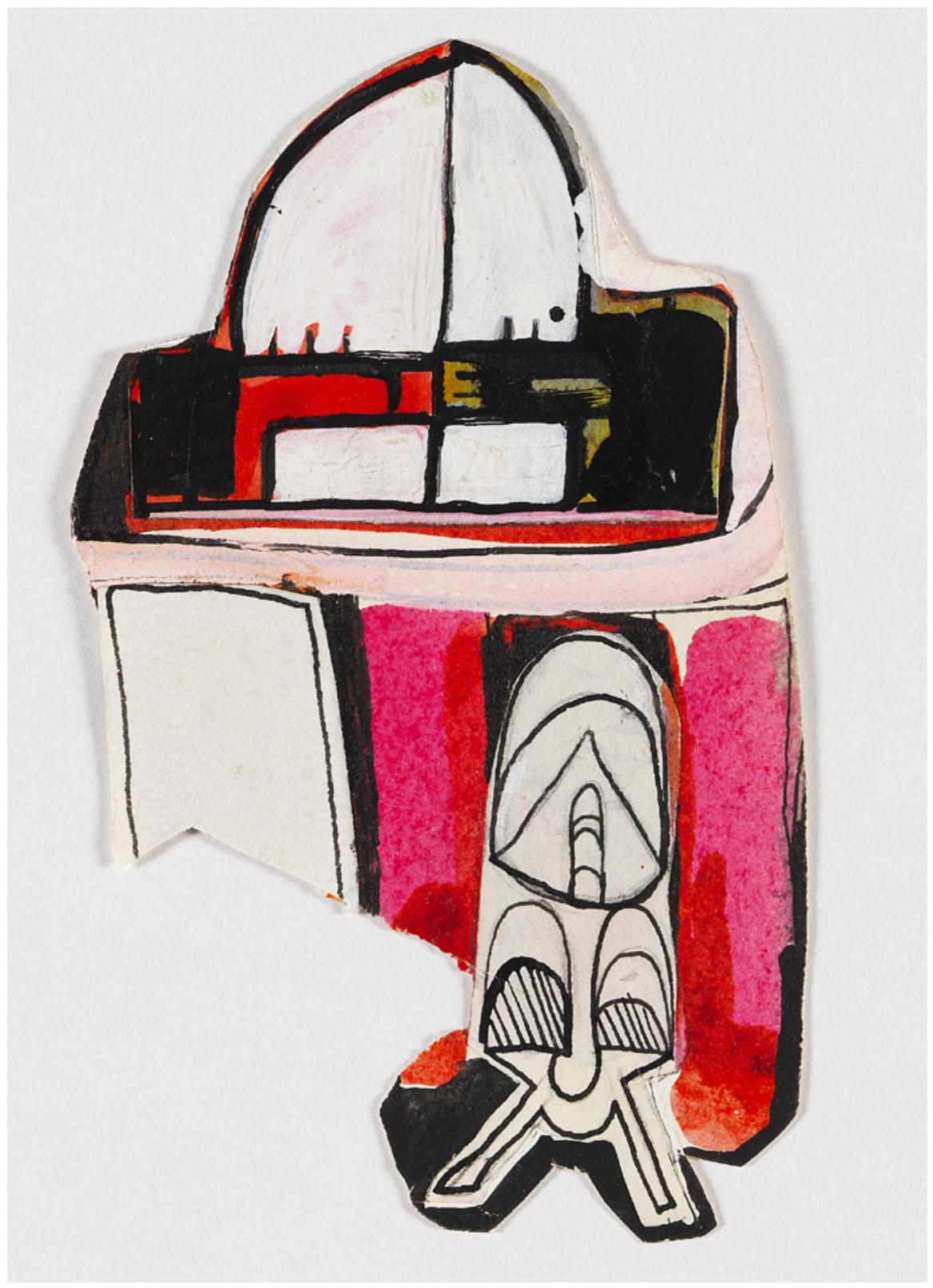

Figure 9 Eva Hesse, Penetration, I965. Collage with acrylic, India ink and watercolour, mounted on board, I $3.5 \times 8.2 \mathrm{~cm}$. fluid archives. (C) The Estate of Eva Hesse. Courtesy Hauser \& Wirth. 
the exhausted remains of a readily available - if faulty and ultimately faltering - toolbox.

Through such works, the experience of painting is recast as a physical process of 'construction, deconstruction, and reconstruction,' as Sillman describes it, which highlights rather than hides 'every saggy place (...) between what you tried and what really happened.' ${ }^{37}$ During an interview given just before her death in 1970, Hesse retrospectively described her painting practice as a move 'backwards. ${ }^{38}$ Rather than regression however, this statement seems to indicate a condition of belatedness similar to that seen in Sillman's own mode of painting. As if to illustrate this, in the inaugural issue of her self-published zine, the O-G, Sillman lays out a lexicon of her imagery (figure Io), recasting the kind of vector recognized in Hesse's work as a makeshift apparatus with which to shape the 'struggle' with the figure of painting itself, rather than

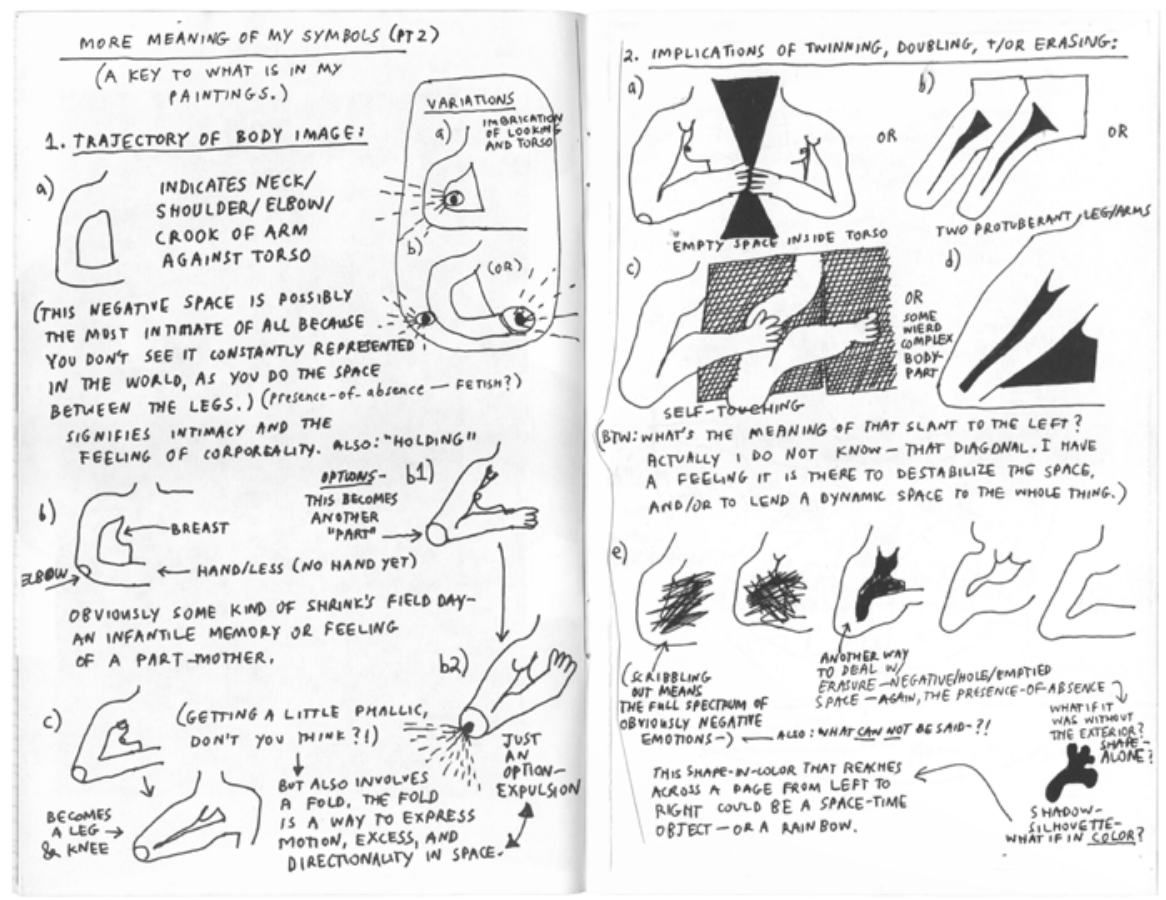

Figure Io Amy Sillman, 'More Meaning of My Symbols (pt. 2) (A Key to What is in My Paintings.)' from the O-G, vol.I/2 (American Edition), 2009. Photocopy, 2 I.6 $\times$ I $4 \mathrm{~cm}$. (C) Amy Sillman. Courtesy of Sikkema Jenkins \& Co., New York. 
figuration or abstraction as such. ${ }^{39}$ Mining the historical equation of 'the paint stroke, the very use of the arm (. . .) to a phallic spurt,' by graphically rehearsing its impotence as a canonical form, Sillman simultaneously calls to mind a tradition of artist's explanatory notes, such as those collated in Marcel Duchamp's Green Box, whilst establishing a framework for her own idiosyncratic procedure. $4^{\circ} \mathrm{W}$ ith their sketchy, arbitrary, and composite details, it is as visual litanies of the dynamics and dilemmas of painting as a fallible experience that Hesse's canvases similarly appear.

Around 1963, Hesse started to incorporate collage into her paintings. Whilst not a sustained practice as such (it seems inappropriate to even call this collage, since the pieces are so finely pasted as to almost elide distinction, let alone disjunction), it would provide a sort of manual manoeuvre with which to trial different forms, from the pre-given, such as crosses, numbers, letters, arrows, even pictures within pictures, to the painterly, in the wide variety of scrubbed, striated and looped brushstrokes, and gestural drips, dabs, and doodles drawn from the same 'reserve' later delved into by Sillman. ${ }^{41} \mathrm{~A}$ crisscrossing of prevalent modes is also seen in one of her works on paper made the previous year (figure I I), in which a visual interplay is set up between the appropriated image (itself a frame full of images) and the rectangular forms and coloured marks that in turn frame it. This is a rare instance of Hesse incorporating a real-world element as it were, but I think it registers a salient step in staking out ways to append the indexical image of representation to abstract elements of gestural picture-making, such as colour, form and line, without putting pay, or 'paying dues,' to either. In this sense, both are 'free' for the taking, as the work so graphically declares. Rather than attempts at mimicry then, Hesse's canvases appear as incremental testing-grounds against which to see what is useful and what is superfluous, what does and does not work within the subjective and compositional graft of 'painting a painting' to quote the artist herself. 'Making art,' as Hesse wrote in I964, 'the Art, the history, the tradition, is too much there (...) I don't want to know the answer before but want an answer that can surprise.' 42

The procedure of turning things around, both physically by cutting and pasting and pictorially by painting, comes to figure a kind of 'phenomenology of making' experienced, I would argue, less in terms of the painter who acts, but the girl who paints - both on her own terms and in her own terminology. When seen in this light, Hesse's canvases take on a pointed criticality of the 


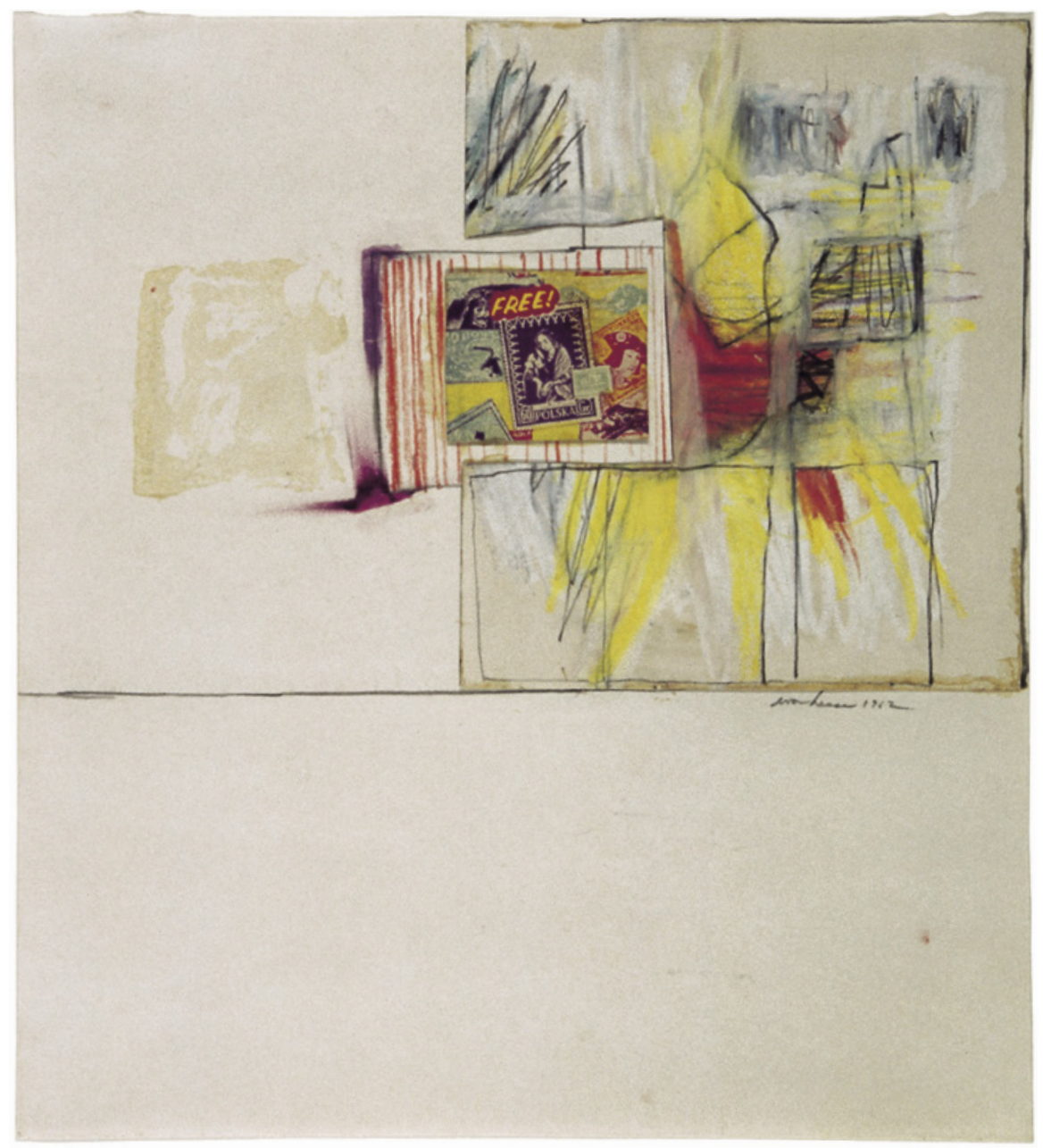

Figure II Eva Hesse, No title, I962. Collage, crayon, and pencil, $25.4 \times 22.5 \mathrm{~cm}$. Allan Memorial Art Museum, Oberlin College, Ohio. (C) The Estate of Eva Hesse. Courtesy Hauser \& Wirth.

common, if specific, artistic experience drolly summarized in a historical anecdote collated by John Cage for his I959 lecture titled Indeterminacy:

One of Mies van der Rohe's pupils, a girl, came to him and said, "I have difficulty studying with you because you don't leave any room for self- 
expression." He asked her whether she had a pen with her. She did. He said, "Sign your name." She did. He said, "That's what I call self-expression."43

'That's what I call self-expression': so comes the authoritative response of a teacher to his pupil, identified simply as 'a girl.'

Like Sillman forty years later, Hesse would retrospectively note her (elder, male) teachers' hostility to her chosen mode of painting, and the control exercised over even the most elemental aspects: 'If you didn't follow their idea, it wasn't an idea. And in color you had to. You were given coloring papers so your choices were less and you had to work within certain confines.' 44 Recognising the teacher's lesson as a betrayal of his own limited purview, the girl here emerges not only as a product of the notably misogynistic discourse surrounding expression and selfhood in art of the midtwentieth century, as well as a construct of that discourse felt across time, but also as a producer who shifts the valence of painting as a pre-given and inherently antagonistic site of artistic production. Trespassing on the bounds of an inherited tradition, Hesse's canvases collectively posit an eye of the needle - or peephole in the fence, to return to Sillman's cartoon - through which to glimpse the possibility of a girl who paints.

\section{Notes}

I would like to thank my supervisor, Briony Fer, for her invaluable support and advice. My thanks also to Dieter Schwarz, Director of the Kunstmuseum Winterthur, and Jörg Daur, Deputy Director and Curator of Modern and Contemporary Art, Museum Wiesbaden, for their kind assistance and generosity during the initial stages of my research towards this paper. For funding my $\mathrm{PhD}$ studies, I am immensely grateful to the London Arts and Humanities Partnership set up by the AHRC. Finally, my thanks to Amy Sillman, Mel Bochner, and the Estate of Eva Hesse for granting image permissions.

I Mark Twain, 'Advice to Little Girls' (I 867), in The \$30,00o Bequest and Other Stories (I906), New York and Oxford, I996, p. 244.

2 Amy Sillman, 'AbEx and Disco Balls: In Defense of Abstract Expressionism II', in Artforum, vol.49, issue no.Io, Summer 20I I, p. 323. In her title, Nancy (thank you to Bushmiller and Brainard), Sillman also references the use of this figure in a series of works by Joe Brainard made during the I960s and I970s. See Joe Brainard, The Nancy Book, New York, 2008. 
3 T.J. Clark, 'In Defense of Abstract Expressionism', in October, vol.69, Summer I994, pp. $22-48$.

4 Sillman, op. cit., p. 322 . Here the phallic appearance of the candy Nancy pokes through the fence takes on a targeted sense of humour.

5 Twain, op. cit., pp. 244-245.

6 Sillman, op. cit., p. $32 \mathrm{I}$. For a discussion of Joan Mitchell's work in relation to this problem see Linda Nochlin, 'Joan Mitchell: A Rage to Paint', in The Paintings of Joan Mitchell, exh. cat., Jane Livingston et.al., New York, 2002, pp. 49-59. Reprinted as 'A Rage to Paint: Joan Mitchell and the Issue of Femininity' (2002), in Women Artists: The Linda Nochlin Reader, Maura Reilly (ed.), London, 20I5, pp. 26 I-273.

7 Sillman, op. cit., p. $32 \mathrm{I}$. In his study on realism in mid-twentieth-century art, Alex Potts cites the term 'identity-oriented politics' as a practical and critical turn of the I980 and I990s, claiming that an opposing interest in 'materialist and collective political engagement' necessitates a certain 'gender bias' resulting in his nearly all-male (and predominantly white) roster of artists. Alex Potts, Experiments in Modern Realism: World Making, Politics and the Everyday in Postwar European and American Art, New Haven, 20I3, pp. I9-20. Lee Krasner quoted in Grace Glueck, 'Scenes from a Marriage: Krasner and Pollock', in ARTnews, No.80, December I98I, p. 6I. For more on the New York School and gender politics see Terence Diggory, 'Questions of Identity in Oranges by Frank O'Hara and Grace Hartigan', in Art Journal, vol.52, issue no.4, Interactions between Artists and Writers, Winter I993, p. 49, and Anne M. Wagner, Three Artists (Three Women): Modernism and the Art of Hesse, Krasner, and O'Keeffe, Berkeley, Los Angeles, and London, I996.

8 Catherine Grant and Lori Waxman, 'Introduction: The Girl in Contemporary Art', in Girls! Girls! Girls! in Contemporary Art, Catherine Grant and Lori Waxman (eds.), Chicago and Bristol, $20 \mathrm{I}_{3}$, p. I.

9 Amy Sillman, 'Affirmative Reaction', in Texte zur Kunst, issue no.84, December 20 I, p. 8o. Earlier in her essay, Sillman asserts that: 'if we repudiate the politics of identity, we are left with a gap of neglectful public articulation, left at the kitchen table in little balkanized ruts complaining to each other privately about how badly we're being treated. I often think about how mere resentment to male privilege is not the same thing as feminism, though the latter could be born from the former.' Ibid., p. 78 .

Io Helen Molesworth, 'Amy Sillman: Look, Touch, Embrace', in Amy Sillman: one lump or two, exh. cat., Helen Molesworth (ed.), Munich, London, and New York, 2013, p. 48. In this light, Nancy's offering of candy can be seen as an instance of the 'double détournement' described in Sillman's text. Ibid., p. 322.

I I See Oranges and Sardines: Conversations on Abstract Painting, exh. cat., Gary Garrels (ed.), Los Angeles, 2008.

I2 Sillman quoted in ibid., p. 66.

I 3 See for example Maria Kreutzer, 'The Wound and the Self: Eva Hesse's Breakthrough in Germany' in Eva Hesse: A Retrospective, exh. cat., Helen A. Cooper et. al., New Haven and London, I992, pp. 75-83. Lucy Lippard also uses the term 'breakthrough' to describe the 'spatially (. . .) disturbing' drawings that would lead to Hesse's reliefs. Lucy R. Lippard, Eva Hesse, New York, I976, p. 27. Referring specifically to Ringaround Arosie (I965), Naomi Spector positions the work as 'a breakthrough into three 
dimensions, as well as an invaluable prototype for the many circle-based works which follow.' Naomi Spector, 'Eva Hesse: The Early Years', in Eva Hesse: Drawing in SpaceBilder und Reliefs, exh. cat., Brigitte Reinhardt (ed.), Ostfildern, I994, p. 48. In his essay on Hesse's drawings, Benjamin Buchloh reiterates the 'dramatic breakthrough' indicated by the reliefs. Benjamin H.D. Buchloh, 'Hesse's Endgame: Facing the Diagram,' in Eva Hesse Drawing, Catherine de Zegher (ed.), New York and New Haven, 2006, p. I28. For more on Hesse's time in Germany see Eva Hesse Transformations - The Sojourn in Germany 1964/65 and Datebooks 1964/1965, exh. cat., Sabine Folie et.al., Vienna, Zurich and London, 2004, and Eva Hesse 1965, exh. cat., Barry Rosen (ed.), New Haven and London, 2013 .

I4 Denoting a finality to the practice of painting by the early I980s, the term 'exit' frames Thomas Lawson's polemical article, 'Last Exit: Painting', in Artforum, vol.2o, issue no.2, October I98I, pp. 40-47.

I5 Yve-Alain Bois, Painting as Model, Massachusetts and London, I990, pp. 24 I-242. Douglas Crimp, 'The End of Painting', in October, vol.r6, Art World Follies, Spring I98I, pp. 69-86.

I6 Two prominent examples are Potts, op. cit., - with the exception of his brief discussion of Niki de Saint Phalle's large 'shooting painting,' King Kong (I963), pp. 3 I3-3 Is - and Hal Foster, The First Pop Age: Painting and Subjectivity in the Art of Hamilton, Warhol, Lichtenstein, Richter and Ruscha, New Jersey and Oxford, 2012. Whilst Potts acknowledges this omission as a result of 'the constitution of the art world in the mid-twentieth century and its very masculinist gender politics,' as well as his own art historical choices, Foster contends that the 'primary' objectification and fetishization of women inherent to Pop art denied them any possibility of also being its main subjects, let alone its producers. Potts, op. cit., p. I9. Foster, op. cit., p. I 5 . Foster does, however, note the emergence in recent years of studies and exhibitions on women Pop artists. Ibid., p. $260 n 36$.

I7 A figure so forcefully outlined, in terms of the history of modern art in America, by Anne Wagner in Three Artists (Three Women), op. cit., I996.

I 8 Especially in regards to the majority of paintings the artist made between I96I-I964. In 2010 an exhibition featuring nineteen of Hesse's canvases from I960, all semi-figurative works never displayed during her lifetime, opened at the Hammer Museum, before travelling to the University of New Mexico Museum, Albuquerque, and the Elizabeth A. Sackler Center for Feminist Art, Brooklyn Museum, New York. See E. Luanne McKinnon (ed.), Eva Hesse Spectres 1960, exh. cat., New Haven, 20 Io. Alison Rowley, amongst others, has discussed the segmented, rectangular paintings that led Hesse more or less directly to the reliefs. Alison Rowley, 'A Painter's Hesse', in Encountering Eva Hesse, Griselda Pollock and Vanessa Corby (eds.), Munich, London, and New York, 2006, pp. I 37-I 52. Overlooking the works made just prior to them, Rowley returns instead to a large canvas completed c.I96I, now in the Museum Wiesbaden collection, which she considers in relation to the so-called 'Color Field' paintings of Helen Frankenthaler. Ibid., p. I47.

I9 Lippard, op. cit, p. 9. The book was first published in I976, six years after Hesse's death.

20 Ibid., p. 24. As Renate Petzinger, co-editor of the catalogue raisonné of Hesse's 
paintings, has asserted: 'the work (she) completed between autumn I959 and autumn I965 is much more significant than had been previously assumed.' Renate Petzinger, 'Thoughts on Eva Hesse's early work 1959-1964', in Eva Hesse, Elisabeth Sussman (ed.), San Francisco, New Haven and London, 2002, p. 42. In regards to the many works on paper Hesse produced alongside her canvases throughout I962-I964, Petzinger goes on to note 'a surprisingly consistent progression involving a step-by-step approach (to the object).' Ibid., p. 47. Also see Eva Hesse Catalogue Raisonné Volume 1. Paintings, Renate Petzinger and Barry Rosen (eds.), New Haven, 2006. Writing for an exhibition held in I994, Naomi Spector sets about connecting what she discerns to be certain 'themes,' 'images' and 'obsessions' in several paintings to the artist's later work. Spector, op. cit., p. 43 .

2 I Mel Bochner quoted in 'About Eva Hesse: Mel Bochner Interviewed by Joan Simon', in Eva Hesse, Mignon Nixon (ed.), Massachusetts, 2002, p. 35.

22 'I don't at this point find the words you're using - "subjective", "compositional" pejorative. They were in the sixties; they were what I bracketed out.' Bochner to James Meyer, quoted in Mark Godfrey, Abstraction and the Holocaust, New Haven, 2006, p. I84. Norman Kleeblatt dates Bochner's return 'to the traditional medium of painting on canvas (although not exclusively)' to c. I979. Norman L. Kleeblatt and Mel Bochner, Mel Bochner: Strong Language, exh. cat., New Haven and New York, 20I4, p. I I 4.

23 It is important to note that at the time of painting Untitled (1964) Bochner did not yet know Hesse, or of her work. Achim Borchardt-Hume describes Bochner's canvas as a 'swamp of faecal-coloured paint.' Borchardt-Hume, 'Colour My Mind', in Mel Bochner: If The Colour Changes, exh.cat., Achim Borchardt-Hume and Doro Globus (eds.), London, 20I2, p. I5. As noted by Hesse in the diary entry for June I9, I964: 'Started work in oil paint today. This is new since last I $1 \frac{1}{2}$ years I used magna paint.' Reprinted in Eva Hesse: A Retrospective, exh. cat., Helen A. Cooper et. al., New Haven, I992, p. 28. Magna paint was favoured at the time by artists such as Helen Frankenthaler, Barnett Newman, Frank Stella, and Morris Louis, as well as Roy Lichtenstein for the black outlines and flat areas of colour in his comic-strip paintings. See Jo Crook and Tom Learner, The Impact of Modern Paints, London, 2000, p. I I 7.

24 For a renewed historical account of the academic tableau, and the implications of its critical role in painting towards the end of the nineteenth century, see Thierry de Duve, 'The Invention of Non-Art, A History', in Artforum, vol.52, issue no.6, February 20I4, pp. I92-I99. Harold Rosenberg, 'American Action Painters' (1952), reprinted in The Tradition of the New, New York, I959, pp. 23-39.

25 In her essay, Sillman states that 'it's not that you're going to be working "like" an AbExer, but the tools themselves will mandate a certain phenomenology of making that emanates from shapes, stains, spills, and smudges.' Sillman, op. cit., 20 I I, p. 322. This 'erasure' refers to Robert Rauschenberg's work, Erased De Kooning Drawing (1953), as cited by Sillman, ibid.

26 Whilst outlining the 'homosocial atmosphere' surrounding the kind of painting under discussion, Clark notes that: 'Vulgarity is gendered, of course. At the time we are examining, it belonged (as a disposable property) mainly to men, or more precisely, to heterosexual men. Not that this meant that the art done under its auspices was closed to reading from other points of view.' Clark, op. cit., p. 40. 
27 Max Kozloff, 'Undertow. The Paintings of Eva Hesse' in Eva Hesse Paintings from 1960 to 1964, exh. cat., New York, I992, u.p.

28 Ibid.

29 Kirsten Swenson, 'Painting Marriage: Eva Hesse's Abstract Expressionism', in Woman's Art Journal, vol.28, issue no.I, Spring-Summer 2007, p. 2 I. In a datebook entry for November 8, I964, Hesse notes seeing an exhibition of Gorky's drawings at the Museum Folkwang in Essen. Eva Hesse, Sabine Folie, Georgia Holz, and Eva Kernbauer, Eva Hesse Datebooks 1964-1965, A Facsimile Edition, vols. I, 2, and 3, New Haven and London, 2006, vol.I, p. I08.

30 My emphasis. See Anna C. Chave, 'Eva Hesse: A "Girl Being a Sculpture”, in Eva Hesse: A Retrospective, exh. cat., Helen A. Cooper et. al., New Haven and London, I992, pp. 99-II7. As Bochner goes on to say in the interview with Joan Simon, '(Hesse's) mythology has taken on a life of its own, making it almost impossible for people to appreciate her real contribution, which was to art history rather than social history. (. . . .) Relying solely on (her) diaries has led some writers to ask some very wrong questions.' Bochner quoted in Nixon (ed.), op. cit., p. 35. Predating the publication of Hesse's diaries and notebooks from her time in Germany, Anne Wagner similarly highlights their (ab)use in past scholarship, yet concludes by identifying these documents as 'an index of purposefulness' on account of their 'immediacy' as recordings of 'self-education and introspection.' Wagner, 'Another Hesse' (I994), in Eva Hesse, Mignon Nixon (ed.), Massachusetts, 2002, pp. I24-I25. Rozsika Parker and Griselda Pollock also note the 'myth' surrounding Hesse in the final chapter of Old Mistresses: Women, Art and Ideology, London, I98 I, p. I54.

3 I Kozloff, op. cit.; Swenson, op. cit., p. 2 I.

32 Catherine Driscoll, Girls: Feminine Adolescence in Popular Culture and Cultural Theory, New York, 2002, pp. 2-I5. Driscoll draws on Michel Foucault's concept of 'genealogy' to frame her argument, presented as 'a map' of 'the effects of particular forms of knowledge about girls' during specific moments throughout the nineteenth and twentieth centuries. Ibid., pp. 3-4.

33 Ibid., p. I5.

34 Swenson states that: 'The breasts or nested ovular forms ostensibly borrowed from Gorky also signal the female identity of the artist.' Swenson, op. cit., p. 2I.

35 For more on Fontana see Anthony White, Lucio Fontana: Between Utopia and Kitsch, Massachusetts and London, 20I I. For a discussion of the trope of the fragmented body in art since the eighteenth century see Linda Nochlin, The Body in Pieces: The Fragment as a Metaphor of Modernity, London, I994.

36 Mignon Nixon has discussed the concept of the 'part-object' of the breast as formed through the psychic drives in relation to Hesse's relief works, which would shortly follow these paintings. See Nixon, 'Ringaround Arosie: 2 in I', in Eva Hesse, Mignon Nixon (ed.), Massachusetts, 2002, pp. I95-2 I 8. Elsewhere she has also considered the phallus as 'part-object' in art of the I950s and I96os. See Nixon, 'Posing the Phallus', in October, vol.92, Spring 2000, pp. 99-I27.

37 Amy Sillman, 'notes on the diagram', in the O-G, vol. I, 2009, u.p.

38 After stating, 'I think at the time (in New York, after Yale) (. . .) I shouldn't say I went backwards, but I did,' Hesse continues: 'It is true, there were stages, but in retrospect - 
the steps - oh, it's so clear.' Italics in original. Cindy Nemser, 'A Conversation with Eva Hesse' (1970), in Eva Hesse, Mignon Nixon (ed.) Massachusetts, 2002, p. 5.

39 Sillman quoted in 'Amy Sillman by R.H. Quaytman', BOMB (Fall 20I3): http:// bombmagazine.org/article/7334/amy-sillman (accessed April 30, 20I4).

40 Sillman, op. cit., 20 I I, p. 32 I. I am thinking here of a twentieth-century tradition stretching from Wassily Kandinsky's Concerning the Spiritual in Art (I9I2), trans. M.T.H. Sadler, New York, I977, through Duchamp's facsimile of notes (originally published under the guise of his female alter-ego, Rrose Sélavy), The Bride Stripped Bare by Her Bachelors, Even (The Green Box), (September, 1934), reproduced in The Bride Stripped Bare by Her Bachelors, Even: a Typographic Version by Richard Hamilton of Marcel Duchamp's “Green Box”, Richard Hamilton (ed.), New York, I960, to the voluminous studies, sketches, and plans made by Öyvind Fahlström from the I960s onwards, and beyond.

4I Achim Hochdörfer, 'A Hidden Reserve: Painting from I958 to I965', in Artforum, vol.47, issue no.6, February 2009, pp. I 52-I 59. For a discussion on the role of collage and assemblage in feminist art, see Miriam Schapiro and Melissa Meyer, 'Waste Not Want Not: An Inquiry into What Women Saved and Assembled - Femmage', in Heresies I, no.4, Winter I977-I978, pp. 66-69.

42 Eva Hesse, diary entry, December Io, I964, in Eva Hesse: A Retrospective, Helen A. Cooper et. al., exh. cat., New Haven and London, I992, p. 3 I.

43 John Cage, 'Indeterminacy' (I959), in Silence: Lectures and Writings by John Cage, London, 2004, p. 269. In 20II, a painting by Hesse completed c. I963-I964 was included as an example of 'self-expression' in Shifting the Gaze: Painting and Feminism, held at the Jewish Museum in New York. Here I want to suggest a more dialectical and complicated historical aspect to such a categorisation. The exhibition also included a painting by Sillman, amongst many others. For an overview of the exhibition see Daniel Bulasco, 'Size Matters: On the Triumph of Feminist Art', in Lilith, Fall 20 Io, pp. 24-29. Although outlining the general curatorial impetus to consider painting through the dual lenses of gender and Judaism, Bulasco does not discuss this specific exhibition category in detail.

44 Hesse quoted in Nemser, op. cit., p. 5. To expand on Hesse's account: 'I think that struggle between (being a) student and finding one's self is, even at the beginning level of maturity, something that cannot be avoided. I don't know anyone who has avoided it.' 'I loved (Josef) Albers' color course but I had had it at Cooper (Union School), I did very well in it. I was Albers' little color studyist - everyone called me that - and every time he walked into the classroom he would ask, "What did Eva do?" (. . . .) But Albers couldn't stand my paintings and, of course, I was much more serious about the painting. I had the abstract expressionist student approach and that wasn't Albers's, not really Rico LeBrun's nor Bernard Chaitin's (sic) approach either.' Ibid. Lippard also notes Hesse's memories of being a student at Yale (with some minor deviation in phrasing from the corresponding passage quoted in Nemser, ibid., p. 4): 'I don't know that the students were bad, but they immediately responded to the tension and friction and uninterest (in the painting department). Albers was past Yale's retirement age but was allowed to remain because they had no one to replace him, and Rico LeBrun and Bernard Chait (sic) fought each other through us. The result was that 
the work wasn't very good.' Lippard, op. cit., p. Io. Mignon Nixon, amongst others, has discussed Hesse's time as a student of Albers. See Nixon, “'Child” Drawing', in Eva Hesse Drawing, Catherine de Zegher (ed.), New York and New Haven, 2006, pp. 27-57. Also see Renate Petzinger, 'Life and Work', in Eva Hesse: One More than One, exh. cat., Hubertus Gaßner, Brigitte Kölle, and Petra Roettig (eds.), Ostfildern, 20I3, pp. I73-I75, and Jeffrey Saletnik, 'Josef Albers, Eva Hesse, and the Imperatives of Teaching', Tate Papers, issue no.7, Spring (April I) 2007: http://www.tate.org. $\mathrm{uk} / \mathrm{research} /$ publications/tate-papers/josef-albers-eva-hesse-and-imperative-teaching (accessed May 22, 2014). 